\section{IJ§ER \\ ISSN: $2149-5939$}

International Journal of Social Sciences and Education Research

Online, https://dergipark.org.tr/tr/pub/ijsser

Volume: 6(1), 2020

\title{
The knowledge and opinions of prospective elementary school science teachers in Turkey regarding renewable energy
}

\author{
Filiz $\operatorname{Kara}^{1}$
}

Received date: $01 / 01 / 2020$

Accepted date: $05 / 04 / 2020$

\begin{abstract}
In this research, it is aimed to determine the knowledge and opinions regarding renewable energy of 64 prospective teachers. The study data were collected by using a questionnaire consisting of 12 open-ended questions, and analyzed using the descriptive analysis method. The study results showed that the prospective teachers were generally of the opinion that renewable energy sources are mainly used by developed countries. In addition, most of the prospective teachers thought that media organs, and scientific meetings and schools should be utilized as platforms for increasing social awareness on renewable energy sources. However, it was also determined that the number of prospective teachers who learned about renewable energy sources from their parents was considerably limited.
\end{abstract}

Keywords: Renewable energy, Prospective science teacher, Teacher education, Sustainable energy

\section{Introduction}

Due to environmental harm caused by non-renewable energy sources and possible depletion of these reserves in the near future, there is a recent, active search for alternative sources to meet current energy demands. For this reason, the importance accorded to renewable energy sources that have the advantage of being reusable, inexhaustible, and environment-friendly has increased considerably in recent times (Thomas, Jennings \& Llyod, 2008; Sevinç, 2009). Due to environmental pollution and global warming caused by fossil fuels used in traditional energy production methods, various international conventions regarding the environment envisage the gradual reduction of fossil fuel consumption (Spence, 2007). The use of renewable energy technologies is necessary to reduce the numerous problems associated with fossil fuel use (Pimental et al., 2002). In this respect, the current century is expected to be one of significant innovations, advances, and developments in the use of renewable energy sources, which represent a clean and inexhaustible source (Marda \& Şahin, 2007).

The term "renewable energy source" refers to sources of energy that are naturally renewed, and can hence be used continually without the risk of depletion. Sources of renewable energy include solar energy, wind energy, hydraulic energy, biomass, geothermal energy, and wave energy (Daugherty \& Carter, 2010; Yıldız, Sipahioğlu \& Yılmaz, 2000).

Nowadays, many countries allocate considerable sums from their budgets to research that seek to resolve environmental problems and to leave a livable environment for future generations. However, a far simpler approach against environmental problems would involve raising individuals with greater environmental awareness (Sevinç, 2009). In order to raise individuals who are environmentally aware, and who contribute to the well-being of their societies with their novel

${ }^{1}$ Dr., Merkez Sehit Ilhan Kusan Secondary School, Samsun, Turkey, karafilizkara@gmail.com 
Kara, F. (2020). The knowledge and opinions of prospective elementary school science teachers in Turkey regarding renewable energy. International Journal of Social Sciences and Education Research, 6(1), 31-40.

and innovative ideas, measures should be taken to provide education regarding the sources of environmental pollution and to instill positive attitudes towards the environment. Such measures would contribute considerably to efforts focusing on the reduction and prevention of pollution.

Teachers play an important role in the development of environmental awareness among students. Ensuring that prospective teachers are knowledgeable regarding renewable energy and energy sources will also allow their students to develop awareness on this subject. In this context, it is important to place emphasis on the education of prospective teachers on renewable energy sources. According to McLaughline (2008), reducing the deterioration of the environment around the globe necessitates a change in the technology-related and social behaviors of students. In institutions that raise teachers, curricula should be planned in such a way that they include courses and topics on renewable and sustainable energy (Marker, 1991; Keser, Özmen \& Akdeniz, 2003). In a research, it is remarked the less educated people who have lacks of knowledge about renewable energy are an obstacle for using these sources (Muresan et al., 2017).

This study was performed to determine the knowledge and opinions regarding renewable energy of prospective teachers receiving their education at the Department of Elementary School Science Teaching of a university in the Black Sea Region of Turkey.

\section{Method}

Single survey model as one of the general survey models has been used in the research. Instant survey model as one of the single survey models was preferred and it is aimed to reveal the current states of students. General survey model is the survey model used to work with the whole universe or a particular group of the universe in order to reach a general judgment about a universe where a large number of elements are available (Bailey, 1982). Single survey model is the identification of the variables in the research separately as variety or amount. In this model, the variables such as events, matters groups, institutions, issue in question are dealt separately (Karasar, 2014). It is possible to make some predictions about the future situations by the data obtained through single survey model. The data obtained in this model can be evaluated by being analyzed by statistical techniques such as arithmetic mean, mode, median, standard deviation, variance analysis, frequency and percentage (Köse, 2010).

The study was conducted with 64 prospective teachers receiving their education at the Faculty of Education, Department of Elementary School Science Teaching of a university in the Black Sea Region of Turkey.

The study used a questionnaire consisting of 12 open-ended questions to determine the knowledge and opinions of science prospective teachers regarding renewable energy sources. The use of open-ended questions allows researchers to evaluate significant variables and to investigate a particular subject by using a flexible approach (Yıldırım \& Şimşek, 2011). The prospective teachers were requested to answer the questions based on their current knowledge, and were allowed sufficient time to answer each question.

The study data were analyzed using the descriptive analysis method. The answers of the prospective teachers were classified into different groups. The ratios of the answers provided by the prospective teachers were shown as frequency (f). 
Kara, F. (2020). The knowledge and opinions of prospective elementary school science teachers in Turkey regarding renewable energy. International Journal of Social Sciences and Education Research, 6(1), 31-40.

\section{Results}

The frequency distribution of the prospective teachers' answers to the question, "Where did you first hear about the concept of renewable energy?" is provided in Table 1.

Table 1. The sources from which prospective teachers first heard about the concept of renewable energy

\begin{tabular}{cc}
\hline Answers & Frequency \\
\hline School & 55 \\
Television & 30 \\
Newspaper & 30 \\
Internet & 25 \\
Friend & 11 \\
Family & 5 \\
\hline
\end{tabular}

Table 1 shows that most of the prospective teachers first heard about the concept of renewable energy from school, television, and newspapers. This observation indicates that schools assume an important role in raising awareness regarding renewable energy, and that television and newspapers are also important tools for raising awareness. In addition, it is interesting to note that the number of prospective teachers who first heard of the concept of renewable energy from their parents was five.

The frequency distribution of the prospective teachers' answers to the question, "What is renewable energy?" is provided in Table 2.

Table 2. The opinions of the prospective teachers on what renewable energy is

\begin{tabular}{cc}
\hline Answers & Frequency \\
\hline An inexhaustible form of energy & 34 \\
A renewable form of energy & 17 \\
A recycled form of energy & 14 \\
Energy that is less detrimental to the environment & 11 \\
Energy formed by natural processes & 7 \\
Energy that exists naturally in the environment & 6 \\
An abundant form of energy & 1 \\
Energy that is more economical & 1 \\
Non-fossil fuel energy & 1 \\
\hline
\end{tabular}

As can be seen in Table 2, the prospective teachers described renewable energy as a form of energy that is inexhaustible, renewable, and less detrimental for the environment. The prospective teachers who provided these answers were fairly knowledgeable regarding renewable energy. However, 14 of the prospective teachers described renewable energy as a type of energy obtained through recycling, which indicated that they confused the concept of renewable energy with recycling.

The frequency distribution of the prospective teachers' answers to the question, "What are examples of renewable energy sources?" is provided in Table 3.

Table 3 shows that the prospective teachers correctly mentioned the sources for biomass energy and hydrogen energy (which are, evidently, biomass and hydrogen). However, the other responses provided by the prospective teachers described "forms" of energy rather than "sources" 
Kara, F. (2020). The knowledge and opinions of prospective elementary school science teachers in Turkey regarding renewable energy. International Journal of Social Sciences and Education Research, 6(1), 31-40.

of energy. In addition, one of the prospective teachers erroneously described fossil fuels as a type of renewable energy source.

Table 3. Examples of renewable energy sources described by the prospective teachers

\begin{tabular}{cc}
\hline Answers & Frequency \\
\hline Wind energy & 62 \\
Solar energy & 59 \\
Geothermal energy & 48 \\
Biomass & 11 \\
Hydrogen & 9 \\
Electrical energy & 8 \\
Wave energy & 4 \\
Hydroelectric energy & 3 \\
Heat energy & 2 \\
Light energy & 1 \\
Fossil fuels & 1 \\
\hline
\end{tabular}

The frequency distribution of the prospective teachers' answers to the question, "What are examples of non-renewable energy sources?" is provided in Table 4.

Table 4. Examples of non-renewable energy sources described by the prospective teachers

\begin{tabular}{cc}
\hline Answers & Frequency \\
\hline Coal & 43 \\
Oil & 35 \\
Natural gas & 35 \\
Fossil fuels & 25 \\
Lignite & \multicolumn{2}{c}{8} \\
Wood & 7 \\
Electrical energy & \multicolumn{2}{c}{4} \\
Light energy & 3 \\
Heat energy & 2 \\
Solar energy & 2 \\
\hline
\end{tabular}

Table 4 shows that most of the prospective teachers correctly provided examples of non-renewable energy sources. However, it was noted that one of the prospective teachers erroneously listed solar energy as a form of non-renewable energy.

As can be seen in Table 3 and Table 4, some of the prospective teachers erroneously described forms of energy such as heat, light, and electrical energy as renewable or non-renewable sources of energy. In addition, it was observed that some of the prospective teachers lacked the level of knowledge to correctly distinguish renewable energy sources from non-renewable energy sources.

The frequency distribution of the prospective teachers' answers to the question, "What are the differences between renewable and non-renewable sources of energy?" is provided in Table 5.

As can be seen in Table 5, some of the prospective teachers expressed that renewable energy sources are less detrimental for nature than non-renewable energy sources, and that renewable energy are renewable and inexhaustible. This indicated that many of the prospective teachers were aware of the differences between renewable and non-renewable energy sources. However, it was noted that seven of the teachers believed that renewable energy sources can be recycled, indicating that they confused the concept of renewable energy with recycling. 
Kara, F. (2020). The knowledge and opinions of prospective elementary school science teachers in Turkey regarding renewable energy. International Journal of Social Sciences and Education Research, 6(1), 31-40.

Table 5. The opinions of the prospective teachers regarding the differences between renewable and non-renewable energy sources

\begin{tabular}{cc}
\hline Renewable energy source / Non-renewable energy source & Frequency \\
\hline Not detrimental to nature / Detrimental to nature & 25 \\
Renewable / Not renewable & 21 \\
Inexhaustible / Exhaustible & 16 \\
Economical / Not economical & 7 \\
Can be recycled / Cannot be recycled & 7 \\
Formed over a short period of time / Formed over a long period of time & 6 \\
Obtained from the natural environment / Obtained from fossil sources & 4 \\
\hline
\end{tabular}

The frequency distribution of the prospective teachers' answers to the question, "What are the advantages of using renewable energy sources to meet energy demands?" is provided in Table 6.

Table 6 . The opinions of the prospective teachers regarding the advantages of using renewable energy sources

\begin{tabular}{cc}
\hline Answers & Frequency \\
\hline Reduction of environmental pollution & 30 \\
Lower costs & 26 \\
Risk of depletion for traditional energy sources & 13 \\
Reusability & 9 \\
Utilization of sources that are natural & 4 \\
No waste or byproducts associated with their use & 2 \\
Reduction of dependency on other countries and imports & 2 \\
\hline
\end{tabular}

Table 6 shows that the prospective teachers associated the use of renewable energy sources with the reduction of environmental pollution and the elimination of any risk regarding the depletion of sources. This result demonstrated that the prospective teachers were aware of the advantages of using renewable energy sources.

The frequency distribution of the prospective teachers' answers to the question, "Should information on renewable energy sources be covered during formal education?" is provided in Table 7.

Table 7. The opinions of the prospective teachers regarding the inclusion of information on renewable energy sources to formal education

\begin{tabular}{cc}
\hline Answers & Frequency \\
\hline $\begin{array}{c}\text { Education on renewable energy sources should be provided to ensure that } \\
\text { future generations are more knowledgeable and have greater awareness re- } \\
\text { garding the environment. }\end{array}$ & 42 \\
\hline $\begin{array}{c}\text { Education should be provided on the importance of renewable energy } \\
\text { sources for a pollution-free environment. }\end{array}$ & 18 \\
\hline $\begin{array}{c}\text { Ensuring that future generations are knowledgeable about renewable energy } \\
\text { sources might allow new projects and innovations to be developed with } \\
\text { these energy sources. }\end{array}$ & 3 \\
\hline There is no link between education and renewable energy sources. & 1 \\
\hline
\end{tabular}

Among the prospective teachers participating in the study, 63 expressed that the subject of renewable energy sources should be included in formal education. As reasons, they have mentioned the necessity to raise individuals who more knowledgeable and have greater awareness 
Kara, F. (2020). The knowledge and opinions of prospective elementary school science teachers in Turkey regarding renewable energy. International Journal of Social Sciences and Education Research, 6(1), 31-40.

regarding the environment, and also that renewable energy sources are necessary for a pollutionfree environment. However, one prospective teacher described that there is no potential relationship between renewable energy and education.

The frequency distribution of the prospective teachers' answers to the question, "How can we raise awareness within society regarding renewable energy?" is provided in Table 8.

Table 8 . The opinions of the prospective teachers on how to raise awareness within society regarding renewable energy

\begin{tabular}{cc}
\hline Answers & Frequency \\
\hline Television & 27 \\
Conference & 22 \\
School & 17 \\
Newspaper & 12 \\
Seminar & 10 \\
Banner & 10 \\
Journal & 8 \\
Advertising & 7 \\
Panel & 7 \\
Brochure & 7 \\
Internet & 6 \\
Media & 6 \\
Symposium & 5 \\
Billboards & 3 \\
Civil society organizations & 3 \\
Trip & 3 \\
Book & 2 \\
Radio programs & 2 \\
Foundation & 1 \\
Public service ad & 1 \\
Project competitions at school & 1 \\
Theater activities at school & 1 \\
\hline
\end{tabular}

As can be seen in Table 8, most of the prospective teachers believed that awareness raising activities should be conducted through media organs (television, newspapers, periodicals, advertisements, and brochures), and through scientific meetings (conferences, seminars, panels, and symposiums). Among the prospective teachers, 17 also believed that awareness raising activities should be conducted in schools.

The frequency distribution of the prospective teachers' answers to the question, "What is the relationship between the use of renewable energy sources and the environment?" is provided in Table 9.

Table 9. The opinions of the prospective teachers regarding the relationship between the use of renewable energy sources and the environment

\begin{tabular}{cc}
\hline Answers & Frequency \\
\hline Renewable energy sources do not harm the environment & 27 \\
Renewable energy sources cause less harm to the environment than other & 17 \\
energy sources & 7 \\
Renewable energy sources are environment-friendly & 1 \\
Renewable energy sources can harm the environment & \\
\hline
\end{tabular}


Kara, F. (2020). The knowledge and opinions of prospective elementary school science teachers in Turkey regarding renewable energy. International Journal of Social Sciences and Education Research, 6(1), 31-40.

As can be seen in Table 9, some of the prospective teachers described that renewable energy sources do not harm the environment, while others described that renewable energy sources cause less harm to the environment than other sources of energy. These results demonstrated that most prospective teachers were aware of the relationship between renewable energy sources and the environment. However, one of the prospective teachers erroneously expressed that renewable energy sources could harm the environment.

The frequency distribution of the prospective teachers' answers to the question, "Do you believe that renewable energy sources are being sufficiently used in Turkey?" is provided in Table 10 .

Table 10. The opinions of the prospective teachers regarding the use of renewable energy sources in Turkey

\begin{tabular}{cc}
\hline Answers & Frequency \\
\hline They are not being sufficiently used in Turkey & 33 \\
Their use in Turkey should be increased & 8 \\
Their use in Turkey has increased in recent years & 5 \\
They are not being used at all in Turkey & 2 \\
No opinion & 1 \\
\hline
\end{tabular}

As can be seen in Table 10, most of the prospective teachers were of the opinion that renewable energy sources are not being sufficiently used in Turkey, and that their use should hence be increased.

The frequency distribution of the prospective teachers' answers to the question, "What are the types of renewable energy used in Turkey?" is provided in Table 11.

Table 11. The views of the prospective teachers regarding the types of renewable energy used in Turkey

\begin{tabular}{cc}
\hline Answers & Frequency \\
\hline Wind energy & 22 \\
Solar energy & 13 \\
Geothermal energy & 6 \\
Hydroelectric energy & 5 \\
Biomass energy & 2 \\
\hline
\end{tabular}

As can be seen in Table 11, most of the prospective teachers were of the opinion that wind energy and solar energy are the most commonly used types of renewable energy in Turkey.

The frequency distribution of the prospective teachers' answers to the question, "To what extent are renewable energy sources being used around the world?" is provided in Table 12.

Table 12. The views of the prospective teachers regarding the use of renewable energy sources around the world

\begin{tabular}{cc}
\hline Answers & Frequency \\
\hline They are used widely around the world & 25 \\
They are used only in developed countries & 17 \\
Their use is limited and should be increased & 13 \\
Their use has increased in recent years & 5 \\
They are not used around the world & 1 \\
No opinion & 3 \\
\hline
\end{tabular}


Kara, F. (2020). The knowledge and opinions of prospective elementary school science teachers in Turkey regarding renewable energy. International Journal of Social Sciences and Education Research, 6(1), 31-40.

As can be seen in Table 12, some of the prospective teachers described that renewable energy sources are widely used around the world. However, 17 of the prospective teachers believed that renewable energy sources are only used in developed countries.

\section{Discussion}

According to the study results, most of the prospective teachers first heard of the concept of renewable energy from school, television, and newspapers. This indicated the importance of education institutions and media organs in raising awareness among individuals regarding renewable energy sources. However, it is also important to bear in mind that education regarding renewable energy sources is a process that begins with the family, and continues during the different and successive stages of education. In fact, as described (Wilson, 1996), education on the environment provided at an early age to students has a positive effect on their future attitudes towards the environment. Yet, the current study results showed that the number of students who first heard of the concept of renewable energy from their parents was limited, indicating that the families themselves lacked any significant awareness regarding renewable energy. This finding was in agreement with the results of a research, which observed that most of respondents pointed out that they don't have enough knowledge about renewable energy and using it in daily life (Muresan et al., 2017).

The most important characteristics of renewable energy sources that distinguish them from non-renewable energy sources are that they are renewable and environmentally friendly. Based on the study results, it was observed that the prospective teachers were fairly knowledgeable regarding these two characteristics of renewable energy. However, some of the prospective teachers described renewable energy as a type of energy obtained through recycling, which indicated that they confused the concept of renewable energy with recycling.

Renewable energy is a type of energy obtained by using renewable and sustainable natural sources such as the wind, sun, underground waters, biomass, hydrogen, rivers, seas, and oceans. They can hence be provided and used continuously without the risk of depletion or pollution. Based on the study results, it was observed that the prospective teachers listed only hydrogen and biomass as renewable sources of energy. The other items they listed were "kinds" of energy rather than "sources" of energy. The underlying reason why the prospective teachers were better at providing examples of non-renewable energy sources (coal, petroleum, natural gas, lignite, and wood) might be associated with the fact that the use of these fossil fuel-based energy sources is more common and widespread. The fact that prospective teachers erroneously listed electricity, heat, and light as renewable or non-renewable sources of energy indicated that they had limited knowledge regarding the production of energy from energy sources.

It was also observed that the prospective teachers associated the use of renewable energy sources with the reduction of environmental pollution and the elimination of any risk regarding the depletion of energy sources. This reflected that the prospective teachers were mostly aware of the advantages of using renewable energy sources. It is supported in a research that a large of respondents accepted that use of renewable energy can supply reduction of energy consumption and can affect climate change positively (Boutakidis, Aggelopoulos, Pavloudi \& Soutsas, 2014).

Among the prospective teachers participating in the study, 63 expressed that the subject of renewable energy sources should be included into formal education. This finding was in agreement with the results of a study, which also observed that most science prospective teachers 
Kara, F. (2020). The knowledge and opinions of prospective elementary school science teachers in Turkey regarding renewable energy. International Journal of Social Sciences and Education Research, 6(1), 31-40.

considered education on renewable energy sources as important (Çelikler, 2013). In the current study, the prospective teachers described that it is necessary to raise awareness among individuals, to educate future generations with greater awareness towards the environment, and to emphasize the importance of renewable energy sources for a pollution-free environment.

The prospective teachers also described that individuals should be informed regarding renewable energy sources through television broadcasts, newspapers, periodicals, advertisements, brochures, conferences, seminars, panels, symposiums, and schools. This result indicated that the prospective teachers were aware of the importance of media organs, and scientific meetings and schools for increasing social awareness on renewable energy sources.

Most of the prospective teachers were of the opinion that renewable energy sources are not being sufficiently used in Turkey, and that their use should hence be increased. Furthermore, many prospective teachers also thought that renewable energy sources are only used by developed countries. This is likely to be associated with their knowledge of the high initial costs necessary to obtain energy from renewable sources, and of the strong incentives provided in developed countries for the production of renewable energy. Due to the gradual increase in the worldwide demands for energy and the rapid depletion of fossil fuels reserves, it is necessary to further develop the use of renewable energy sources and to increase their share in the overall energy consumption. The production of energy from renewable energy sources will contribute to the protection of the environment and also to decreasing a country's dependence on energy imports. In this respect, it is important to increase the usage of renewable energy sources by making the necessary investments, and to raise awareness among individuals regarding the characteristics and benefits of energy produced from renewable energy sources. In this context, it is essential for prospective teachers (as well as the students they will later instruct) to be properly informed about renewable energy sources, and to be knowledgeable about their significance for sustainable development.

\section{Conclusion}

Based on the study results, it was determined that the prospective teachers had adequate knowledge regarding renewable energy sources, and were mostly aware of their importance and advantages.

It was determined that prospective science teachers remarked that heard the expression of renewable energy from school, television and newspaper. However, it was also determined that the number of prospective teachers who learned about renewable energy sources from their parents was considerably limited.

It was determined that the prospective science teachers were awareness that renewable energy sources are renewable and environmentally friendly. In addition, they pointed out that use of renewable energy sources can be effective on reduction environmental pollution and elimination risk of depletion of energy sources.

In this study results, it was determined that the prospective teachers remarked only hydrogen and biomass as renewable sources of energy but they listed the other renewable sources as "kinds" of energy rather than "sources" of energy.

63 of prospective science teachers remarked that formal education should include subject of renewable energy. 
Kara, F. (2020). The knowledge and opinions of prospective elementary school science teachers in Turkey regarding renewable energy. International Journal of Social Sciences and Education Research, 6(1), 31-40.

Prospective teachers thought that educational institution like school, scientific meetings like conference, seminar, panel, symposium, and media organs like television, newspaper, banner and journal should be effective for increasing people's social awareness about renewable energy sources.

The study results showed that the prospective teachers thought that renewable energy sources are mainly used by developed countries. They also thought that renewable energy sources are not used sufficiently in Turkey and should be increased the using of them.

\section{References}

Bailey, K. D. (1982). Methods of social research (2 ${ }^{\text {nd }}$ edition). New York: The Free Press.

Boutakidis, D., Aggelopoulos, S., Pavloudi, A. \& Soutsas, K. (2014) Attitudes and opinions of social media users on renewable energy. Journal of Environmental Protection and Ecology, 15(4), 1727-1734.

Çelikler, D. (2013). Awareness about renewable energy of pre-service science teachers in Turkey. Renewable Energy, 60, 343-348.

Daugherty, M. K. \& Carter, V. R. (2010). Renewable energy technology: It Is imperative that current students become aware of and familiar with emerging renewable energy technologies and how these technologies will continue to influence their lives in the $21^{\text {st }}$ century. The Technology Teacher, 69(5), 2428.

Karasar, N. (2014). Scientific research method (27 th edition). Ankara: Nobel Publication Distribution.

Keser, Ö. F., Özmen, H. \& Akdeniz, F. (2003). Energy, environment, and education relationship in developing countries' policies: A case study for Turkey. Energy Sources, 25, 123-133.

Köse, E. (2010). “Scientific research models", Scientific research methods, R. Y. Kıncal (ed.). Ankara: Nobel Publication Distribution, 97-120.

Marda, O. \& Şahin, Ü. (2007). Global warming and climate crisis: Why cannot we wait more. Istanbul: Agora Library Publishing.

Marker, G. W. (1991). Has the time come to revive energy education? Social Studies, 82(5), 183-187.

McLaughlin, C. (2008). Career connections: Environmental occupations. Technology and Children, 13(1), 14-15.

Muresan, I. C., Chiciudean, G. O., Harun, R., Arion, F. H., Porutiu, A., Chiciudean, D. I., Oroian, I. G \& Jitea, M. I. (2017). Constraints on use of renewable energy technologies in the rural area: A Case Study from the North-West Region of Romania. Journal of Environmental Protection and Ecology, 18(4), 1746-1753.

Pimental, D., Herz, M., Glickstein, M., Zimmerman, M., Allen, R., Becker, K., Evans, J., Hussain, B., Sarsfeld, R, Grosfeld, A. \& Seidel, T. (2002). Renewable energy: Current and potential issues. Bioscience, 52(12), 1111- 1120.

Sevinç, V. (2009). General environment science. Ankara: Maya Academy.

Spence, S. (2007). Global warming (Translate by S. Gönen, S. Apar). Ankara: Pegasus Publishing.

Thomas, C, Jennings, P. \& Llyod, B. (2008). Issues in renewable energy education. Australian Journal of Environmental Education, 24, 67-73.

Wilson, R. A. (1996). Environmental education programs for preschool children. Journal of Environmental Education, 27(4), 28-33.

Yıldırım, A. \& Şimşek, H. (2011). Qualitative research methods in the social sciences ( $8^{\text {th }}$ edition). Ankara: Seçkin Publishing.

Yıldız, K., Sipahioğlu, Ş. \& Yılmaz, M. (2000). Environment science. Ankara: Gündüz Education and Publishing. 